\title{
Research on Vocabulary in Chinese Commercial Contracts
}

\author{
Chunxiang $\mathrm{Wu}$ \\ Shanghai International Studies University, Shanghai, China \\ Jennifer Baccanello \\ Shanghai International Studies University, Shanghai, China
}

\begin{abstract}
Business English has already become a major field in linguistics. In contrast, Business Chinese has not seen the same level of activity, which is reflected in the comparatively small amount of teaching resources and related research on Business Chinese. One important example of a context in which business language is used is the commercial contract. This study is an analysis of the classification and characteristics of vocabulary used in Chinese commercial contracts.
\end{abstract}

Index Terms - commercial contract, business Chinese vocabulary, business language, legal language

\section{INTRODUCTION}

Business is a fundamental activity for human beings. In order for us to communicate in business, we use the sublanguages of business and business communication. Bargiela-Chiappini et al. (2007) define business discourse as "all about how people communicate using talk or writing in commercial organizations to get their work done" (p. 3). This study focuses on exploring the commercial contract, an important document commonly used in everyday business activity, so that we can conduct both a quantitative and qualitative description on the vocabulary used in Chinese commercial contracts. In society, contracts are made between natural persons or legal persons in order to carry out a particular purpose. Contracts clearly stipulate the rights and obligations of parties to the contract, thus resulting in a document that has legal validity. Given that our world has become more interconnected and globalisation has now become mainstream, contracts play a critical role in how individuals, companies, governments and so on, interact with each other in business. For those involved in the legal aspects of doing business, such as negotiators, lawyers, translators and so on, they are expected to be familiar with the linguistic characteristics of commercial contracts so that they can accurately understand the clauses drafted in contracts and can either reduce or remove any risks that could give rise to an unfortunate situation for the parties to the contract. As a formal legal document, the style of writing in commercial contracts has both characteristics of business language as well as legal language. This paper looks at the features of language used in Chinese commercial contracts including nouns, verbs, formal language, general language, legal language, standardization, as well as its precise and dynamic nature.

\section{BUSINESS LANGUAGE}

Sager et al. commented, "the lexicon of special languages is their most obvious distinguishing characteristic" (1980, p. 230), and that the main characteristics of specialized discourse include its economical nature, precision and appropriateness (1980, p. 323). Aurner (1940) described Business English as "[t]he vocabulary of business is that wide, inclusive, vigorous, and sometimes technical group of English words used for the purpose of making business operations efficient and successful" (p. 15). Given that linguists have already paid particular attention to the vocabulary that comprises Language for Specific Purposes in the case of English, we believe that the vocabulary used in Business Chinese also merits our attention. Business Chinese has been described as being communicative, goal-oriented, practical and having a professional nature (Deng, 2018, p. 161), yet these characteristics have only been described on the basis of subjective opinion and analysis, lacking data-based support and objectivity. Therefore, the purpose of this paper is to carry out a statistical analysis of the vocabulary found in a database of Chinese commercial contracts.

In a study by Wu Haiyan (2014) titled "Research on the vocabulary of Business Chinese" (Shangwu Hanyu Cihui Yanjiu - 商务汉语词汇研究), Wu conducted both theoretical research and applied pedagogical research on the vocabulary of Business Chinese. This research incorporated a range of texts as the focus of the study, including Business Chinese teaching resources, a corpus from Peking University's Centre for Chinese Linguistics, two EnglishChinese bilingual dictionaries, a grading scheme on syllabic lexicon for Chinese International Education, and an examination syllabus for the Business Chinese Test from Peking University's Office of Research and Development. Wu discovered that the vocabulary used in Business Chinese and general Chinese have their respective differences and similarities, and particularly, that seven different features (see Table 1) characterise Business Chinese. 


\section{RESUltS OF ANALYSIS OF CHINESE COMMERCIAL CONTRACTS}

The data used in our study come from authentic commercial contracts, that is, naturally occurring corporate language. The 40 contracts totaling 254,960 characters used were freely provided on official Chinese business and government websites. The data tabulated in this study are given in terms of absolute frequency. In order to make this study as representative as possible in terms of Chinese commercial contracts, we attempted to use a variety of commercial contracts differing in terms of format, purpose and content. Given the difficulty of obtaining authentic commercial documents, there is a duplication of a small number of contracts: Sale of Goods Contract (货物买卖合同) (3), Sales Contract (销售合同) (3), Purchase and Sale Contract (买卖合同) (2) (see Appendix A for all contracts used in this study). Naturally, given the wide range of commercial contracts that exist, this study has not been able to include all types of commercial contracts into the analysis. To carry out a statistical measurement of the vocabulary used in the contracts outlined in Appendix A, we used the Python programming language in order to obtain the relevant data.

Table 2 below shows the different parts of speech found in our database of Chinese commercial contracts. As can be seen from the results, nouns are the most frequently used part of speech.

TABLE II.

Parts of Speech in Database of Chinese Commercial Contracts

\begin{tabular}{|c|c|c|c|}
\hline Part of speech & Example & Marker & Frequency in database \\
\hline Noun & 合同 & $\mathrm{NN}$ & 61027 \\
\hline Verb & 应 & VV & 26232 \\
\hline Adverb & 依次 & $\mathrm{AD}$ & 7032 \\
\hline Cardinal number & $1,2,3$ & $\mathrm{CD}$ & 6933 \\
\hline Preposition & 在 & $\mathrm{P}$ & 6587 \\
\hline Coordinating conjunction & 与, 和, 或者 & $\mathrm{CC}$ & 4903 \\
\hline Non-describable adjective & 共同 & $\mathrm{JJ}$ & 4390 \\
\hline Auxiliary word (的) & 的 & DEC & 4319 \\
\hline Determiner & 这, 那 & DT & 3847 \\
\hline “的” as a marker of possession & 的 & DEG & 3628 \\
\hline Measure word & 条, 本, 款 & M & 3117 \\
\hline Noun of locality & 上, 下, 后, 前 & LC & 2781 \\
\hline Proper noun & 中国 & NR & 2208 \\
\hline Ordinal number & 第一 & OD & 1184 \\
\hline Pronoun & 双方 & PN & 1183 \\
\hline Linking verb & 是 & VC & 649 \\
\hline Verb & 有, 没有, 无 & $\mathrm{VE}$ & 594 \\
\hline Adjective & 先进 & VA & 579 \\
\hline Auxiliary word & 所, 以, 而 & MSP & 536 \\
\hline Etcetera (等) & 等 & ETC & 450 \\
\hline Noun for time & 当月 & NT & 378 \\
\hline Subordinating conjunction & 如果, 要是 & CS & 345 \\
\hline Preposition (被) & 被 & SB & 206 \\
\hline Preposition (把) & 把 & $\mathrm{BA}$ & 171 \\
\hline Modal particle & 了, 吧, 吗 & SP & 112 \\
\hline Auxiliary word (地) & 地 & DEV & 97 \\
\hline Preposition (被) & 被 & LB & 89 \\
\hline Aspect particle & 了, 着, 过 & AS & 69 \\
\hline Auxiliary word (得) & 得 & DER & 2 \\
\hline
\end{tabular}


TABLE III.

20 MOST COMMON FUNCTION WORDS AND CONTENT WORDS

\begin{tabular}{|c|c|c|c|}
\hline Content word & Frequency & Function word & Frequency \\
\hline 合同 & 2918 & 的 & 8203 \\
\hline 本 & 2284 & 和 & 1521 \\
\hline 份 & 2061 & 在 & 1670 \\
\hline 款 & 1963 & 或 & 1651 \\
\hline 有 & 1627 & 为 & 1280 \\
\hline 不 & 1620 & 及 & 1007 \\
\hline 期 & 1327 & 对 & 876 \\
\hline 甲方 & 1313 & 所 & 826 \\
\hline 第 & 1272 & 并 & 800 \\
\hline 乙方 & 1290 & 与 & 784 \\
\hline 日 & 1257 & 由 & 764 \\
\hline 管理 & 1207 & 之 & 615 \\
\hline 条 & 1174 & 按 & 560 \\
\hline 可 & 1092 & 向 & 541 \\
\hline 内 & 979 & 将 & 476 \\
\hline 后 & 848 & 因 & 411 \\
\hline 应 & 844 & 按照 & 308 \\
\hline 下 & 800 & 根据 & 283 \\
\hline 规定 & 782 & 被 & 246 \\
\hline 贷款 & 721 & 或者 & 201 \\
\hline
\end{tabular}

Table 3 shows the most frequently used words in our database of Chinese commercial contracts. We have analysed these according to the traditional classification method of content words and function words, in which the former contain a practical meaning and can independently form sentences as they have a lexical meaning as well as grammatical meaning, while the latter only have either a grammatical meaning or functional meaning and cannot independently form sentences.

\section{ANALysis of the LeXICAL ChaRACTERISTICS OF ChINESE COMMERCIAL CONTRACTS}

In this section, we undertake an analysis of the vocabulary used in our database of Chinese commercial contracts.

\section{A. Analysis of Parts of Speech: Nouns and Verbs}

From Table 2 we can see that the most frequently used part of speech in our database is the noun, with a tendency to express concrete concepts, such as 基金 (fund), 技术 (technology), 产品 (product), 项目 (project), and so on. The second most frequently used part of speech is the verb, with a tendency to use verbs to express cooperation or trade between two parties: 提供 (to provide), 制造 (to manufacture; to make), 使用 (to use), 采用 (to use, adopt), 交付 (to deliver; to hand over), 支付 (to pay), 收到 (to obtain, to receive), and so on. We also found that many affixes have a strong ability to reproduce new words when combined with different characters. In such cases, their position is relatively fixed, while maintaining both a sense of its lexical meaning as well as revealing a tendency of how the part of speech is used to form new words. The examples below show how three different characters, "期" (time; period), “证” (certificate; proof) and “费” (cost; expense; fee), are used in our database of Chinese commercial contracts to form new words.

期:

日期, 延期, 船期, 按期, 保证期, 有效期, 保质期, 星期, 到期, 逾期, 交货期, 履约期, 同期, 每期, 分期, 前期, 合作 期, 保期, 任期, 工期, 保修期, 质保期, 长期, 周期, 即期, 定期, 首期, 如期, 非分期, 当期, 存续期, 活期, 短期, 预 期, 可延期, 中期, 限售期, 报告期, 不定期, 免仓期, 犹豫期, 假期, 试用期.

证: 
单证, 信用证, 保证, 用证, 公证, 可证, 凭证, 签证, 身份证, 鉴证, 不保证, 教师证, 暂住证, 房产证, 开证, 权证, 合 格证, 许可证, 查证, 签证, 验证, 认证, 使用证, 开证, 离婚证, 执业证, 不保证.

费:

服务费, 滞期费, 仓储费, 保险费, 运费, 空仓费, 检验费, 装卸费, 差旅费, 消费, 经费, 损失费, 公证费, 诉讼费, 仲 裁费, 过户费, 律师费, 建筑费, 生活费, 医药费, 路费, 收费, 电费, 管理费, 自费, 培训费, 补助费, 运杂费, 保养费, 计费, 税费, 免费, 浪费, 安装费, 包装费, 住宿费, 招待费, 发布费, 制作费, 印刷费, 人工费, 杂费, 鉴定费, '旅费, 补偿费, 加工费, 保险费, 保障费, 工费, 耽搁费, 自费, 转让费, 入门费, 使用费.

From Table 3, we can see that the most frequently used verbs in our database are: 有 (to have; to possess), 管理 (to manage), 应 (ought to; should), 规定 (to stipulate). In the legal context, the modal verb “应” emphasises binding norms in legal texts, that is, it stipulates behavior that a party must do or is prohibited from doing (Yu Zhichun, 1991, p. 26). In Table 4, we have measured and compared the use of various modal verbs in our database of Chinese commercial contracts. It can be noticed that “应”, a low-to-medium value modal verb is used more frequently than other modal verbs. Below are examples of the use of “应” as found in our database of contracts:

(1) ...买方或其船方代理应及时通知卖方。

(2) 采用自主支付的，甲方应定期报告或告知乙方贷款资金支付情况...

The negative form of “应”in our database is not “不应”, but is expressed as“不得”, as shown below:

TABLE IV.

\begin{tabular}{l} 
TABLE IV. \\
\begin{tabular}{|c|c|} 
FREQUENCY OF MODAL VERBS \\
\hline Modal verb & Frequency \\
\hline 应 & 844 \\
\hline 应当 & 282 \\
\hline 可以 & 158 \\
\hline 不得 & 120 \\
\hline 必须 & 108 \\
\hline 不能 & 107 \\
\hline 需要 & 92 \\
\hline 可能 & 83 \\
\hline 能 & 58 \\
\hline 禁止 & 25 \\
\hline 能够 & 12 \\
\hline 应该 & 4 \\
\hline 务必 & \\
\hline
\end{tabular} \\
\hline
\end{tabular}

(3) 乙方有下列情况之一的，甲方不得解除合同...

(4) ...在基金募集行为结束前, 任何人不得动用。

In a contract, “应当” and “必须” can be both translated into English as either "must” or "shall”. Therefore, L2 Chinese learners may find it useful to pay attention to the following point: while “应当” and “必须” may not be substantially different, “应当” is typically used in the legal context to refer to an obligatory norm rather than using “必 须" .

\section{B. Stylistic Analysis: Written Language and Spoken Language}

Chinese contracts typically come in a written format and utilise formal language with relatively little oral or colloquial language, which shows the formality and solemnity that characterises this type of document. The results from this study are consistent with this view. For example, we found a relatively high number of conjunctions (和, 及, 并, 与, 或者), which is characteristic of formal written language. However, unlike other formal written business documents, we found that our database of contracts did not adhere to principles of politeness. For example, some formal written business documents employ language used to show courtesy and respect. In Chinese, a business letter may use language such as “盼望贵方佳音” (we look forward to hearing from you soon), “扰贵方 X 月 X 日来函询问之事, 我们很遗憾

\footnotetext{
${ }^{1}$ See: 《立法工作规范（试行一）》（法工委发 [2009] 62 号文）.
} 
的奉告..." (regarding the letter that was sent on $X$, we regret to inform you that...") and so on, conforming to the principles of politeness. Moreover, business letters can also use the passive tense to create a mild or gentle tone, yet in our database of commercial contracts, it was found that the passive tense was used to a relatively small degree.

From our results, it can be seen that there is a relatively high use of professional terminology, consisting of both Business Chinese and Legal Chinese, as seen in the following vocabulary: 信用证 (letter of credit), 不可抗力 (force majeure), 撤销 (to repeal), 法定代表人 (legal representative), 债权人 (creditor), 保证人 (guarantor), 合同签订地 (place of signing a contract), 委托方 (principal), 验收工作 (project acceptance), 串标行为 (colluding behaviour in bidding), 有效性 (validity; effectiveness), 约束力 (binding force), 简易程序 (summary procedure), 账簿 (account book), 著作权 (copyright), 清偿 (pay off; clear off), 债务 (debt; liability), 法律效力 (legal force), 仲裁 (arbitration), 权利义务转让 (transfer of rights and obligations), 唛头 (shipping mark), 违约金 (liquidated damages; penal sum), 著 作权 (copyright), 解除合同 (terminate a contract), 解约 (terminate an agreement), 出口国 (exporting country), 增值税 (added-value tax), 管辖权 (right of jurisdiction), 利率 (interest rate), 浮动比率 (floating-rate).

We also found a particular group of vocabulary that while typically used in general Chinese, can take on a different meaning when used in a commercial contract. Accordingly, these words can be considered to be specialised vocabulary. For example, in general language, the term “责任” (duty; obligation) may not necessarily refer to a legal duty or obligation, but can simply refer to responsibility that a person has. In a legal context such as a commercial contract, the term “责任” refers to a legal duty or legal obligation, and can be interpreted in both a general and a narrow sense. By interpreting “责任” in a general sense, it refers to the responsibility of a group or individual to abide by the law, in which people consciously uphold their duties according to law while. The narrow meaning of the term “责任” refers to the responsibility that a lawbreaker owes for having carried out an unlawful act, and therefore, it is a duty or obligation that has legal force.

Given that Chinese commercial contracts contain a large amount of specialised vocabulary such as 管辖 (jurisdiction), 自由销售 (free sale), 约束力 (binding force), 要约 (offer), 默认条款 (implied term), 默许 (acquiescence), L2 Chinese learners who have not undertaken Chinese for Special Purposes (CSP) courses in the field of Business Chinese and Legal Chinese may face particular challenges. Moreover, an L2 Chinese learner may have successfully passed a high level of Chinese such as the highest level of the HSK examination, yet this may not automatically prepare a student to face the challenges of learning vocabulary contained in specialised documents such as commercial contracts. Given that the vocabulary listed in the HSK syllabus is general in nature, numerous words found in our database of commercial contracts are not listed in the HSK syllabus, such as: 美元 (US dollar), 仲裁 (arbitration), 装运 (shipping; loading and transport), 金额 (money; sum; figure), 失效 (invalid; to lose efficacy), 毛重 (gross weight), 总值 (total value; gross value), 履约 (to honour an agreement), 承付 (honour; to promise to pay), 越过 (to cross; to surmount; to negotiate), 争 执 (dispute). This finding supports the fact that new and relevant CSP materials are important for L2 Chinese learners who use Chinese in a business or legal context. The research results shows that Chinese commercial contracts have a high level of professional language, and that contract drafters use standardized vocabulary. Examples 5-7 below show how specialised vocabulary is used in our database of contracts:

（5）提前还款通知自到达贷款人之日起生效，提前还款通知是不可撤销的，借款人有义务按照其中注明的金 额和日期提前还款。

(6) 通过管理人网站查询等方式知悉有关集合计划运作的信息，包括资产配置、投资比例、损益状况等 ...

(7) “提成费”指在本合同有效期内，由于乙方所给予甲方连续的技术咨询和援助，以及甲方在合同有效期内 连续使用乙方的商标和专有技术，甲方向乙方支付的费用。

Although Business Chinese incorporates a large amount of specialized business terminology, one of its main characteristics is its specificity or clarity. Therefore, in order to ensure that both parties to a contract clearly understand its content, there is typically a large amount of general language as well business language, and naturally, different types of contracts also have different levels of specialisation. For example, one of the contracts examined titled "Personal Loan Contract" utilised a significant amount of language that has overlaps between business language and general language, as evidenced in the use of the following vocabulary: 费用, 公证, 分期, 还款, 借款, 方式, 执行, 调整, 登记. Compared to other types of specialized discourses, it may be said that the language used in Chinese commercial contracts has a lower degree of technical terminology compared to specialized discourse such as Medical Chinese (医学 汉语) or Chinese used in other scientific fields such as chemistry (化学汉语) where specific terminology is used that would not be used in general Chinese.

\section{Industry Analysis}

Following the swift development in China's economy, Business Chinese has naturally evolved. Therefore, from the perspective of sociolinguistics, we can explore the development of Business Chinese. The US linguist W. Bright considered that sociolinguistic research covers seven different aspects, of which is language change and the application of sociolinguistics (Bright, 1966). From this perspective, we can take a closer look at the changes of vocabulary used in 
our database of Chinese commercial contracts. We used the historical retrieval function in the online BCC corpus to examine two particular vocabulary, “仲裁” (arbitration) and “不可抗力” (force majeure).

The first recording of “仲裁” in the BCC corpus was in 1946, and 41 records of its use were found in that year. ${ }^{2}$ For example:

主佃相继发言后, 即进入仲裁, 首先是解决业主汤仍千与佃户的纠纷（汤有一百二十六亩地在教场乡, 本 人在上海未归, 由庄头王树仁为代表）。（人民日报，1946）

Over the $20^{\text {th }}$ and early $21^{\text {st }}$ century, usage of “ “仲裁” in the BCC corpus saw an increase, and by 2001 it had been used 546 times. We can also see new types of collocations with the word “仲裁”:

我国仲裁制度的完善和对新形势的适应与否，直接关系到我国进一步改革开放的步伐和在国际合作和竞争关 系中的地位。（人民日报，1946）

From this example (仲裁制度), we can see that “仲裁” is not used merely as an independent word, but following the evolution of new systems in global business, it has been paired with the noun “制度” (system) to describe a range of systems, such as: 经济仲裁制度 (economic arbitration system), 劳动仲裁制度 (labor arbitration system), 体育仲裁制 度 (sport arbitration system), 现代仲裁制度 (modern arbitration system), 劳动争议仲裁制度 (labor dispute arbitration system), 美国现代仲裁制度 (modern US arbitration system), and 涉外仲裁裁决撤销制度 (system of repeal of arbitration award concerning foreign interests).

Similarly, the BCC corpus has a recording in 1949 of “不可抗力” being used: ${ }^{3}$

甲、因天灾事变或其他不可抗力致损失者。(人民日报, 1950)

Previously in China, the legal phrase “不可抗力” (force majeure) had not existed, but following globalisation and the development of China's economy, the phrase has been introduced into legislation and is commonly used in business and legal documents. The origin of “不可抗力” lies in the French Civil Code and the term “force majeure”. By 1985, China put forward a clear interpretation of the meaning of “不可抗力” in its legislation: force majeure refers to an event that is unforeseen by the parties at the time of making a contract, and where its occurrence and consequences cannot be avoided and overcome. The scope of force majeure can be agreed on by the parties and written into the contract. ${ }^{4}$ Although, the initial scope of “不可抗力” was limited to natural events such as floods, droughts and earthquakes, its scope has been broadened to include human events such as wars, riots, fires, and terrorism (Traore \& Xiao, 2001). Thus, we can see that following China's societal development, the meaning of “不可抗力” has evolved.

\section{Other Characteristics}

Standardization: From the words of the late Qing dynasty thinker, Liang Qichao, we know that Chinese legal language possessed certain fundamental criteria: "Legal language has three important elements: it must be clear, authentic and forceful." Given that commercial contracts are a type of written document, they are able to give play to their own language, one which can express legal meaning. Unlike general language, legal language in contracts can impose obligations on parties, confer legal rights upon parties, and contracts themselves can be used as legal evidence in the case of a dispute. Therefore, given the legal role played by language in contracts, we can see a degree of standardization in the vocabulary used in contracts, so as to conform with tradition. For example, in our database of Chinese commercial contracts, these are some of the standard legal terminology found throughout the contracts: 不可抗 力 (force majeure), 履约 (to honour an agreement), 补偿金 (compensation), 违约金 (liquidated damages; penal sum), 履行 (performance), 违反 (to violate), 委托人 (principal; consignor), 解除 (to discharge; to relieve), 仲裁 (arbitration), 受让方 (acquiring party; transferee), 出让方 (granter; transferor), 侵权 (tort; infringement), 义务 (obligation; duty), 业 绩报酬 (performance-based compensation)、撤销 (to cancel; to repeal).

Precision: From Table 4, we can see that the commercial contracts have a high frequency of measure words, such as 份, 款, 期,日, 条, reflecting an important characteristic of contracts, namely, its precision. We also found that our database of commercial contracts includes a significant amount of legal language. Legal language has been described as using vocabulary that is extremely precise and as having a purpose that is extremely clear and definite (Mellinkoff, 1963, p. 21), however, it is also important to pay attention to the fact that legal language can also be characterised as having a particular degree of vagueness or flexibility (Gibbons, 2003, p. 38). For example, in example (8) below, we can see how the character "等” (etcetera) is used to include a whole series of unfavourable changes in circumstances

\footnotetext{
2 “仲裁” (arbitration) BCC data: 荀恩东, 绕高琦, 肖晓悦, 藏娇娇. 大数据背景下 BCC 语料库的研制[J]，语料库语言学，2016(1).

3 “不可抗力” (force majeure) BBC data: 荀恩东, 绕高琦, 肖晓悦, 藏娇娇. 大数据背景下BCC 语料库的研制 $[J]$, 语料库语言学，2016(1).

${ }^{4}$ Original text: “不可抗力是当事人在订立合同时不能预见，对其发生和后果不能避免并不能克服的事件。不可抗力事件的范围，可以在 合同中约定。”Source:《中华人民共和国涉外经济合同法》第 24 条第 3 款.

${ }^{5}$ Original text: “法律之文辞有三要件：一日明，二日确，三曰弹力性，明、确就法文之用语言之，弹力性就法文所含意义言之”. Source: 梁启超先生 1904 年发表的《论中国成文法编制之沿革得失》。
} 
that could occur, thereby making the contract make able to deal with any unforeseen changes in circumstance. In examples 9 to 10 below, we can see that although the character “等” creates an airy of ambiguity or vagueness, it also helps to ensure that the contracts are more operative and complete.

(8) 甲方及担保人民事行为能力和经济状况是否发生不利变化等事项, 并根据审查结果决定是否发放贷款, 此类审查不构成乙方的义务。

(9) 乙方所提供的技术资料应有统一的符号、统一的标准、统一的规范等，不得有任何矛盾。

(10) 根据实际需要, 乙方有义务向甲方派遣专家并为甲方培训必要的技术人员, 来厂专家和培训人员的数 目、时间、任务以及费用负担等, 由双方另行商议。

Dynamic nature: Following the development of business activity, a continuous number of new words have come into being to help describe business activity. From the Chinese commercial contracts included in this study, we found the following new words had been used:

并购 (merger and acquisition), 上市 (appear on the market; to be listed), A 股 (A-share), 普票 (ordinary VAT invoice), 追偿 (pursuing of recovery), 联营 (joint operation; consortium), 高利货 (high interest), 贴现 (discount), 贴现 率 (discount rate), 保证金 (cash deposit), 招投标 (tender; bid), 专利权 (patent right), 包退 (guarantee of replacement).

Moreover, our research results also included numerous foreign words, with foreign words from Japanese making up a significant proportion, and also abbreviated words. We referred to the resource titled "Dictionary of Chinese Foreign Words" (Hanyu Wailaici Cidian - 汉语外来词词典) (Gao Mingkai, 1984) and found that our database of Chinese commercial contracts includes the following foreign words from Japanese:

登记 (register), 电话 (telephone), 复制 (duplicate; copy), 故障 (fault; malfunction), 关系 (connection), 广告 (advertisement), 国际 (international), 回收 (reclaim), 机械 (machinery), 集中 (concentrate; focus on), 计划 (plan; project), 记录 (record), 交换 (exchange), 进度 (plan; schedule; rate of progress), 进展 (progress; evolve), 经验 (experience), 具体 (specific), 会计 (accountant; accounting), 类型 (type; form), 了解 (understand), 年度 (end of year), 评价 (evaluation), 权益 (benefit; interest), 实绩 (actual performance), 法人 (legal person), 统计 (statistics), 证券 (security; stock), 政策 (policy), 清算 (clearing; liquidation), 自由 (freedom), 电子 (electronic), 服务 (service), 劳动 (labour; work), 分配 (distribution; allocation), 基准 (standard; criterion), 金额 (money; sum), 金融 (finance), 经济 (economy), 企业 (enterprise), 商业 (business; commerce), 业务 (business; operation), 债权 (creditor's rights), 投机 (speculate).

We also found a small number of foreign words from English, such as: 软件 (software), 硬件 (hardware), 硬盘 (hard disk), 信息点 (POI - point of information), 数据库 (database). Regarding the use of abbreviated words, our database found that a number of Chinese commercial contracts use abbreviated forms of proper nouns. For example, 美国元 (US dollar) was abbreviated to 美元, 中证投资 (China Securities Information) was abbreviated to 中证, 股本权证 (equity warrant) was abbreviated to 权证, and 中华民国 (Republic of China) was abbreviated to 中华. Our database also found a number of other non-proper nouns, such as 财产权 (property right) being abbreviated as 产权.

\section{IMPLICATIONS FOR TEACHING AND CONCLUDING REMARKS}

From our analysis on Chinese commercial contracts, we have found that the vocabulary used in Chinese contracts is predominantly made up of nouns compared to other word types. For the purposes of teaching Chinese as a second language, we can see that many nouns can be taught according to their word groups, which is particularly helping for L2 Chinese learners who are studying the vocabulary of business Chinese. This study also shows that vocabulary in Chinese commercial contracts does not only consist of technical and specific vocabulary, but also of common words that can take on a particular meaning in the context of a contract, and thus it is important for L2 Chinese learners to be aware of these different meanings. Within CSP, word frequency analysis can help identify vocabulary grading and selection in language learning, as "the more frequently a word occurs, the more important it is for a learner to know" (Thoma, 2011, p. 107). Finally, this study shows how corpora can be used to facilitate understanding of terminology used in fields such as business and law, by helping students become aware of high-frequency terminology. To continue this line of research, we seek to carry out cross-linguistic research so that we can gain a deeper understanding of how terminology and formulaic language differs between languages in the context of commercial contracts. Moreover, apart from vocabulary, we can fully grasp the characteristics of business Chinese by exploring it from the perspective of commonly used sentence patterns in business Chinese, commonly used conventional expressions in business Chinese, and commonly used forms of wording in business Chinese (Deng Jingyi, 2018, p. 161). 
Appendix. Different Types of Chinese Commercial Contracts Used in This Study

\begin{tabular}{|c|c|c|c|c|c|c|c|}
\hline Name & Amount & Name & Amount & Name & Amount & Name & Amount \\
\hline $\begin{array}{c}\text { Sale of Goods } \\
\text { Contract (货物买 } \\
\text { 卖合同) }\end{array}$ & 3 & $\begin{array}{c}\text { Insurance Agent } \\
\text { Contract (保险代理合 } \\
\text { 同) }\end{array}$ & 1 & $\begin{array}{c}\text { Personal Loan } \\
\text { Contract (个人贷款 } \\
\text { 合同) }\end{array}$ & 1 & $\begin{array}{c}\text { Compensation } \\
\text { Trade Contract for } \\
\text { Purchase and Sales } \\
\text { (补偿贸易购销合 } \\
\text { 同) }\end{array}$ & 1 \\
\hline $\begin{array}{c}\text { Contract of } \\
\text { Guaranty (保证 } \\
\text { 合同) }\end{array}$ & 1 & $\begin{array}{c}\text { Personal Credit Loan } \\
\text { Contract (个人信用借 } \\
\text { 款合同) }\end{array}$ & 1 & $\begin{array}{l}\text { Contract for Sino- } \\
\text { Foreign Joint } \\
\text { Venture (中外合资 } \\
\text { 经营企业合同) }\end{array}$ & 1 & $\begin{array}{c}\text { Marketing Service } \\
\text { Contract (市场宣传 } \\
\text { 服务合同) }\end{array}$ & 1 \\
\hline $\begin{array}{c}\text { Business } \\
\text { Commission } \\
\text { Contract (业务委 } \\
\text { 托合同) }\end{array}$ & 1 & $\begin{array}{c}\text { International } \\
\text { Commercial Contract } \\
\text { (国际商业合同) }\end{array}$ & 1 & $\begin{array}{c}\text { Contract for } \\
\text { International Sale of } \\
\text { Goods (货物销售合 } \\
\text { 同) }\end{array}$ & 1 & $\begin{array}{c}\text { Service Contract } \\
\text { (服务合同) }\end{array}$ & 1 \\
\hline $\begin{array}{c}\text { Personal Small } \\
\text { Consumer Loan } \\
\text { Contract (个人小 } \\
\text { 额消费贷款合 } \\
\text { 同) }\end{array}$ & 1 & $\begin{array}{c}\text { Securities Investment } \\
\text { Fund Contract (证券投 } \\
\text { 资基金合同) }\end{array}$ & 1 & $\begin{array}{l}\text { Product Purchase } \\
\text { and Sale Contract } \\
\text { (产品房买卖合同) }\end{array}$ & 1 & $\begin{array}{c}\text { Brand Service } \\
\text { Contract (品牌服务 } \\
\text { 合同) }\end{array}$ & 1 \\
\hline $\begin{array}{c}\text { Sino-Foreign } \\
\text { Joint Venture } \\
\text { Contract (中外合 } \\
\text { 作经营企业合 } \\
\text { 同) }\end{array}$ & 1 & $\begin{array}{c}\text { Construction Project } \\
\text { Consulting Contract (建 } \\
\text { 设工程造价咨询合同) }\end{array}$ & 1 & $\begin{array}{c}\text { International } \\
\text { Trademark } \\
\text { Licensing Contract } \\
\text { (国际商标许可合 } \\
\text { 同) }\end{array}$ & 1 & $\begin{array}{c}\text { International } \\
\text { Propriety License } \\
\text { Contract (国际专有 } \\
\text { 技术许可合同) }\end{array}$ & 1 \\
\hline $\begin{array}{c}\text { Labor Contract } \\
\text { for Foreign- } \\
\text { Invested } \\
\text { Enterprises (外商 } \\
\text { 投资企业劳动合 } \\
\text { 同) }\end{array}$ & 1 & $\begin{array}{c}\text { Collective Asset } \\
\text { Management Contract } \\
\text { (期集合资产管理合同) }\end{array}$ & 1 & $\begin{array}{c}\text { International } \\
\text { Technology } \\
\text { Transfer Contract } \\
\text { (国际技术转让合 } \\
\text { 同) }\end{array}$ & 1 & $\begin{array}{c}\text { Contract for System } \\
\text { Integration Project } \\
\text { (系统集成项目合 } \\
\text { 同) }\end{array}$ & 1 \\
\hline $\begin{array}{l}\text { Sales Contract } \\
\text { (销售合同) }\end{array}$ & 3 & $\begin{array}{l}\text { Personal Borrowing and } \\
\text { Lending Contract (个人 } \\
\text { 消贷易额度及支用借 } \\
\text { 款合同) }\end{array}$ & 1 & $\begin{array}{c}\text { Contract for } \\
\text { Technology Import } \\
\text { (技术引进合同) }\end{array}$ & 1 & $\begin{array}{c}\text { Contract for } \\
\text { Intelligent System } \\
\text { Construction } \\
\text { Project (智能系统 } \\
\text { 建设项目合同) }\end{array}$ & 1 \\
\hline $\begin{array}{l}\text { Purchase and Sale } \\
\text { Contract (买卖合 } \\
\text { 同) }\end{array}$ & 2 & $\begin{array}{l}\text { Processing Contract for } \\
\text { Chinese and Foreign } \\
\text { Supplied Materials (中 } \\
\text { 外来料加工合同) }\end{array}$ & 1 & $\begin{array}{c}\text { International } \\
\text { Technology Service } \\
\text { Contract (国际技术 } \\
\text { 服务合同) }\end{array}$ & 1 & $\begin{array}{c}\text { Contract for } \\
\text { Science and } \\
\text { Technology Project } \\
\text { Consulting Service } \\
\text { (科技项目咨询服 } \\
\text { 务合同) }\end{array}$ & 1 \\
\hline $\begin{array}{l}\text { International Sale } \\
\text { of Goods } \\
\text { Contract (国际货 } \\
\text { 物买卖合同) }\end{array}$ & 1 & $\begin{array}{c}\text { International Patent } \\
\text { Technology License } \\
\text { Contract (国际专利技 } \\
\text { 术许可合同) }\end{array}$ & 1 & & & & \\
\hline
\end{tabular}

\section{REFERENCES}

[1] Aurner, R. R. (1940). Effective English in Business. New York: South-western Pub. Co.

[2] Bargiela-Chiappini, F., C. Nickerson \& B. Planken. (2007). Business Discourse. Basingstoke: Palgrave, Macmillan.

[3] Bright, W. (ed.) (1966). Sociolinguistics. Proceedings of the UCLA Sociolinguistics Conference, 1964. The Hague: Mouton.

[4] Deng, Jingyi. (2018). Review on the Last Two Decades of Business Chinese Research (Jin Ershi Nian Shangwu Hanyu Yanjiu Shuping). Language Teaching Research 4, 162-166.

[5] Gibbons, J. (2003). Forensic Linguistics. Oxford: Blackwell Publishing Ltd.

[6] Mellinkoff, D. (1963). The Language of the Law. Boston: Little, Brown.

[7] Sager J.C., D. Dungworth \& P.F. McDonald. (1980). English Special Languages. Wiesbaden: Brandstetter.

[8] Thoma, D. (2011). Strategic Attention in Language Testing. Metacognition in a Yes/No Business English Vocabulary Test. Frankfurt am Mein: Peter Lang. 
[9] Traore, M. \& Y. Xiao. (2011). A Comparative Study of Contract Formation and Breach of Contract and Liability in China and Ohada (Note 1) Space Contract Laws. Journal of Politics and Law, Vol 4(2), 153-161.

[10] Wu, Haiyan. (2014). Research on Business Chinese Vocabulary (Shangwu Hanyu Cihui Yanjiu). Beijing: China Book Publishing House.

[11] Yu, Zhichun. (1991). Discussion of Verbal Phrases in Legal Language (Shilun Falv Yuyan Zhong de Dongciduanyu). Journal of Guizhou Administrative Institute of Politics and Law 1, 25-27.

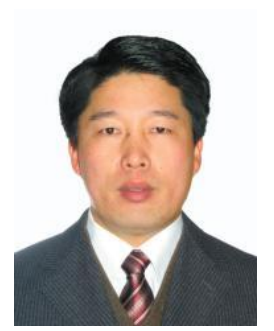

Chunxiang $\mathbf{W u}$ is a professor and $\mathrm{PhD}$ supervisor at Shanghai International Studies University. Mr. Wu studied linguistics and applied linguistics at Yanbian University where he obtained a Master of Arts. He then studied linguistics and applied linguistics at Shanghai Normal University where he obtained his $\mathrm{PhD}$ degree. Mr. Wu's research interests include syntax, rhetorical studies, sociolinguistics and the Teaching of Chinese as a Foreign Language.

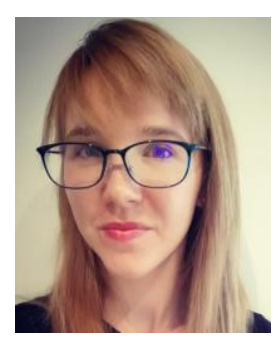

Jennifer Baccanello is currently a PhD candidate for the course Teaching Chinese as a Second Language at Shanghai International Studies University where she is undertaking research on Business Chinese. She has a Bachelor degree in law from Flinders University, Adelaide, Australia (2014) and a Master degree in International Relations from Shandong University, Jinan, China (2016). 